\title{
PENGARUH PERILAKU BELAJAR, KETERAMPILAN SOSIAL, DAN KEANGGOTAAN DI UKM TERHADAP WAKTU PENYELESAIAN STUDI
}

\author{
Yuwanti Kurnia Sari \\ Kurniawan Ali Fachrudin
}

\begin{abstract}
The time of study completion is a matter that need to be taken into account by students during the learning process. In this case, students have considered an adults who could be responsible for themselves and their activities. They are given the freedoom to follow the various of Students Activity Unit (UKM) since entered Ahmad Dahlan University. In the process of election, the students are able to choose the activity accordance with their interests and talents. By following the Students Activity Unit, they are expected to have a good social skill. This study aims to determine the influence of learning behavior, social skills, and membership in Students Activity Unit (UKM) on the time of study completion. The population are bachelors degree students of Accounting Studies Program at Ahmad Dahlan University, with criteria sampling of students who had been followed the final examination. This study took sample of 40 respondents with using purposive sampling method. Based on the data results of the test which has been done by using multiple regression model, showed that whole of independent variable (behavior learning, social skills, and membership Students Activity Unit) has no effect toward the dependent variable (the time of study completion).
\end{abstract}

Keywords: the time of study completion, behavior learning, social skills, membership in Students Activity Unit (UKM)

\section{PENDAHULUAN}

Perguruan tinggi merupakan lembaga pendidikan yang membekali peserta didiknya dengan pemahaman yang menggabungkan antara teori dan pengaplikasiannya dalam dunia kerja. Keberhasilan mahasiswa dalam menempuh pendidikan di perguruan tinggi tidak lepas dari peran dosen sebagai tenaga pendidik dan juga peserta didik. Waktu tempuh studi mahasiswa berbeda-beda di setiap Universitas. Lama studi di Universitas Ahmad Dahlan (UAD) adalah minimal 8 semester (4 tahun) dan maksimal 14 semester (7 tahun) untuk mahasiswa S1. Masa studi adalah rentang waktu yang disediakan bagi mahasiswa untuk menyelesaikan program pendidikan. Aziza (2011), mengemukakan bahwa masa studi yang ditempuh mahasiswa dipengaruhi oleh beberapa faktor seperti perilaku belajar, lingkungan, minat, model pembelajaran dan intelegensi, serta faktor teori belajar. 
Faktor-faktor tersebut akan memiliki pengaruh yang berbeda pada setiap mahasiswa. Setidaknya terdapat tiga tipe mahasiswa yang terdapat di perguruan tinggi, yaitu mahasiswa yang aktif di kelas, mahasiswa yang aktif berorganisasi, dan mahasiswa yang aktif di kelas dan berorganisasi.

Menempuh pendidikan di perguruan tinggi, mahasiswa diberi kebebasan untuk menentukan pilihannya. Selain mengikuti kegiatan kuliah, mahasiswa dapat mengikuti kegiatan di luar kemahasiswaan yang banyak berdiri sebagai Unit Kegiatan Mahasiswa (UKM) yang ada di perguruan tinggi. Bergabungnya seorang mahasiswa dalam Unit Kegiatan Mahasiswa (yang selanjutnya akan disebut UKM) tertentu, diharapkan mahasiswa dapat lebih memiliki keterampilan sosial, dan mampu mengembangkan bakat-bakat yang ada dalam dirinya. Keterampilan sosial adalah kemampuan individu untuk berkomunikasi efektif dengan orang lain baik secara verbal maupun nonverbal sesuai dengan situasi dan kondisi tertentu.

Keterampilan sosial erat kaitannya dengan organisasi dan kegiatan bermasyarakat. Mahasiswa yang aktif di kegiatan organisasi memiliki keterampilan sosial yang lebih tinggi dibandingkan dengan mahasiswa yang tidak aktif berorganisasi. Dengan demikian, mahasiswa yang memiliki keterampilan sosial akan mampu untuk berbicara dan mengungkapkan permasalahan yang dihadapi dan menemukan penyelesaian yang adaptif, memiliki tanggung jawab yang tinggi dalam segala hal, penuh pertimbangan, dan memiliki pengendalian diri terhadap pengaruh-pengaruh negatif yang berasal dari lingkungan. Seseorang yang kurang memiliki keterampilan sosial akan mengalami kesulitan perilaku, kesulitan emosional, mendapatkan penolakan dari rekan, kesulitan dalam bergaul, tidak percaya diri dan kesulitan dalam berkonsentrasi sehingga mempengaruhi aktivitas akademisnya. Berdasarkan uraian tersebut maka penulis bermaksud mengadakan penelitian yang mengenai pengaruh perilaku belajar, keterampilan sosial, dan keanggotaan di ukm terhadap waktu penyelesaian studi.

\section{TINJAUAN PUSTAKA DAN PENGEMBANGAN HIPOTESIS}

\section{Waktu Penyelesaian Studi}

Universitas Ahmad Dahlan (UAD) adalah salah satu universitas swasta yang ada di Indonesia. Sistem pendidikan di UAD adalah dengan mengambil sistem kredit 
semester (SKS). Sistem ini memungkinkan mahasiswa untuk memilih mata kuliah yang ingin dipelajari dalam kurun waktu satu semester dengan prasyarat tertentu. Dengan sistem SKS ini memungkinkan mahasiswa mengambil kembali (re-take) mata kuliah yang memiliki nilai yang kurang memuaskan. Hal ini sangat membantu mahasiswa, terutama bagi mahasiswa yang memiliki kesibukan di luar kegiatan kuliah. Namun sebenarnya hal ini juga memiliki potensi negatif yang membuat mahasiswa kesulitan menyelesaikan waktu studinya. Banyak kasus yang menunjukkan bahwa mahasiswa banyak menumpuk beban mata kuliahnya, hal ini menyebabkan mahasiswa akan kesulitan pada semester-semester berikutnya. Mahasiswa dapat mengetahui dan mengevaluasi hasil pendidikannya dengan melihat nilai yang pada perguruan tinggi disebut Indeks Prestasi (IP). Terdapat dua jenis IP yaitu IP Semester dan IP Kumulatif.

Perguruan tinggi memiliki tugas pokok untuk menyelenggarakan pendidikan dan pengajaran, melakukan penelitian dan pengembangan serta pengabdian kepada masyarakat. Ketiga tugas pokok tersebut dikenal dengan Tridharma Perguruan Tinggi. Dharma tersebut ialah kewajiban untuk melaksanakan pendidikan dan pengajaran, pengabdian kepada masyarakat, dan penelitian serta pengembangan. Ketiganya dapat ditempuh secara berurutan sesuai dengan ketentuan yang ada pada universitas. Waktu tempuh studi jenjang Strata-1 UAD adalah selama 8 semester. Selama 8 semester tersebut mahasiswa diharapkan mampu menjalankan Tridharma Perguruan Tinggi. Oleh karena itu,, mahasiswa dituntut untuk mampu membagi waktu dan menargetkan waktu tempuh studinya.

\section{Faktor-faktor yang mempengaruhi Waktu Penyelesaian Studi Perilaku Belajar}

Ali (1992), mengemukakan bahwa belajar adalah proses perubahan perilaku akibat interaksi individu dengan lingkungan. Ahmadi (1993), lebih jauh menyatakan bahwa belajar adalah suatu perubahan di dalam diri manusia sehingga apabila setelah belajar tidak terjadi perubahan dalam diri manusia maka dapat dikatakan bahwa tidak terjadi proses belajar dalam dirinya. Kebiasaan belajar mahasiswa erat kaitannya dengan manajemen waktu. Mahasiswa harus mampu membagi waktu baik waktu untuk kuliah, belajar di rumah, dan bermain atau bekerja. Strategi belajar dan manajemen waktu yang baik akan mengarahkan 
mahasiswa pada hasil belajar yang maksimal. da hasil belajar yang maksimal. Rampengan (1997), berpendapat bahwa dalam proses belajar diperlukan perilaku belajar yang sesuai dengan tujuan pendidikan agar tujuan tersebut dapat dicapai secara efektif dan efisien sehingga prestasi akademik dapat ditingkatkan. Prestasi akademik merupakan hasil akhir dari proses belajar.

\section{Keterampilan Sosial}

Kelly (dalam Gimpel \& Merrel, 1998), mengemukakan bahwa keterampilan sosial merupakan perilaku-perilaku yang dapat dipelajari, yang digunakan oleh individu pada situasi-situasi interpersonal dalam lingkungan. Keterampilan sosial, baik secara langsung maupun tidak langsung dapat membantu seseorang dalam menyesuaikan diri dengan lingkungan. Fase perkembangan, salah satu keterampilan yang harus dikuasai oleh remaja madya dan remaja akhir adalah memiliki keterampilan sosial (sociall skill). Keterampilan sosial tersebut dapat berupa kemampuan untuk berkomunikasi dan menjalin hubungan dengan orang lain, menghargai diri sendiri dan orang lain, mendengarkan pendapat atau keluhan dari orang lain, serta memberi atau menerima respon dan kritik dengan baik.

\section{Keanggotaan di UKM}

Organisasi intra kampus merupakan sebuah organisasi kemahasiswaan yang memiliki peran penting dalam Perguruan Tinggi. Organisasi mahasiswa intra kampus terdiri dari dua bentuk yaitu Badan Eksekutif Mahasiswa (BEM) dan Unit Kegiatan Mahasiswa (UKM). UKM tersebut banyak berdiri sebagai wadah bagi mahasiswa untuk menyalurkan minat dan bakat yang dimiliki serta menjadi wahana bagi mahasiswa untuk berempati dengan situasi yang terjadi di masyarakat dalam rangka memperoleh pengetahuan yang lebih ekspansif di luar bangku kuliah. UKM melatih mahasiswa untuk fokus terhadap dua kesibukan yaitu lingkup kemahasiswaan dan lingkup realita masyarakat yang sebenarnya.

\section{Pengaruh Perilaku Belajar terhadap Waktu Penyelesaian Studi.}

Mahasiswa dikatakan telah menyelesaikan studi apabila telah menempuh semua mata kuliah dan melewati ujian komprehensif, ujian pendadaran skripsi, dan yudisium. Sebelum melewati masa-masa ini dalam perjalanannya mahasiswa mengalami 
berbagai kendala seperti keterlambatan pengambilan mata kuliah, prestasi akademik yang kurang memuaskan, biaya, dan persyaratan lain dari universitas. Menurut Hamalik (1983), dalam menyelesaikan studinya, mahasiswa menerima banyak pengaruh dari internal dan eksternal. Salah satu faktor yang bersumber dari dalam diri sendiri adalah kebiasaan belajar, atau lebih tepatnya perilaku belajar. Perilaku belajar mahasiswa dapat dilihat dari hasil akademik yang dicapai mahasiswa. Mahasiswa yang memilki perilaku belajar yang baik akan memperoleh nilai akademik yang baik.

H1: Perilaku belajar berpengaruh terhadap waktu penyelesaian studi.

\section{Pengaruh Keterampilan Sosial terhadap Waktu Penyelesaian Studi.}

Ciri-ciri individu yang memiliki keterampilan sosial adalah proaktif, prososial, serta saling memberi dan menerima secara seimbang. Ciri-ciri tersebut banyak terdapat pada mahasiswa. Mahasiswa memiliki berbagai kegiatan di luar universitas yang cukup padat. Kegiatan tersebut sering kali membuat mahasiswa menjadi lupa akan tanggung jawab yang dipikulnya yaitu belajar. Awal pembahasan penulis telah memberikan ulasan mengenai kriteria-kriteria mahasiswa yang terdapat di perguruan tinggi. Salah satu kriteria menyebutkan bahwa mahasiswa yang aktif akan memiliki kegiatan di luar kampus yang lebih padat sehingga lebih memprioritaskan kegiatan sosialnya dan oleh sebab itu aktifitas akademiknya menjadi terganggu.

H2: Keterampilan sosial berpengaruh terhadap waktu penyelesaian studi.

\section{Pengaruh Keanggotaan di UKM terhadap Waktu Penyelesaian Studi.}

Organisasi berasal dari kata organon yang dalam bahasa Yunani diartikan sebagai alat. Penelitian ini UKM dapat dikatakan sebagai alat untuk menampung dan menyalurkan apresiasi mahasiswa melalui pelatihan dan keterampilan sehingga mampu melahirkan mahasiswa yang berpotensi dan berguna bagi masyarakat. Namun secara fenomenalogis, banyak mahasiswa aktivis organisasi yang nilai akademisnya rendah dibandingkan mahasiswa pasif. Hal ini bisa terjadi dikarenakan ada kemungkinan mahasiswa terlalu aktif tanpa diimbangi dengan kegiatan yang dapat menunjang aktivitas kuliah sehari-hari. Bedasarkan hal tersebut, dapat diasumsikan bahwa organisasi kemahasiswaan dapat menghambat 
aktivitas kuliah.

H3: Keanggotaan di UKM berpengaruh terhadap waktu penyelesaian studi.

\section{METODA PENELITIAN}

\section{Populasi dan Sampel}

Populasi penelitian ini adalah mahasiswa S1 jurusan Akuntansi UAD. Teknik pengambilan sampel pada penelitian ini adalah dengan purposive sampling. Kriteria pengambilan sampel pada penelitian ini adalah:

1. Objek penelitian ini dibatasi pada mahasiswa S1 Jurusan Akuntansi Universitas Ahmad Dahlan.

2. Mahasiswa telah mengikuti ujian pendadaran atau menyelesaikan studinya.

\section{Variabel Dependen}

Variabel dependen dalam penelitian ini adalah waktu penyelesaian studi. Peneliti mengambil sampel dari mahasiswa yang telah mengikuti ujian pendadaran. Variabel diukur secara kuantitatif menggunakan jumlah semester yang telah ditempuh oleh mahasiswa sejak semester pertama di bangku kuliah.

\section{Variabel Independen}

\section{Perilaku Belajar (X1)}

Perilaku belajar merupakan kebiasaan belajar yang dilakukan secara terusmenerus oleh individu sehingga menjadi otomatis dan berlangsung secara spontan. Variabel perilaku belajar diukur menggunakan sub-variabel sebagai berikut:

1) Kebiasaan mengikuti pelajaran, yaitu seberapa aktif mahasiswa dalam mengikuti pelajaran dan seberapa besar perhatian yang digunakan untuk mengikuti pelajaran.

2) Kebiasaan membaca buku, yaitu berapa lama mahasiswa membaca buku dan jenis buku apa yang dibaca.

3) Kebiasaan mengatur waktu belajar, yaitu seberapa baik mahasiswa bisa membagi waktu dan mampu disiplin terhadap jam belajarnya.

4) Keaktifan dalam pelajaran, yaitu seberapa baik mahasiswa mampu berinteraksi di dalam kelas. 
Indikator variabel perilaku belajar akan diukur dengan menggunakan skala Likert.

\section{Keterampilan Sosial $\left(\mathbf{X}_{2}\right)$}

Keterampilan Sosial (X2), merupakan kemampuan seseorang untuk berani berbicara, mengungkapkan setiap perasaan atau permasalahan yang dihadapi dan menemukan penyelesaian yang adaptif, memiliki tanggung jawab yang tinggi dalam segala bidang, penuh pertimbangan, dan mampu mengatasi pengaruh negatif yang berasal dari lingkungan. Indikator variabel keterampilan sosial akan diukur dengan menggunakan skala Likert.

Keterampilan sosial diukur dengan sub-variabel sebagai berikut:

a. Hubungan dengan teman, ditunjukkan melalui perilaku yang positif terhadap teman sebaya.

b. Manajemen diri, kemampuan untuk mengontrol emosi, mengikuti peraturan yang ada, dan menerima kritikan dengan baik.

c. Kemampuan akademis, ditunjukkan melalui pemenuhan tugas secara mandiri dan menyelesaikan tugas secara individual.

d. Kepatuhan, ditunjukkan dengan dapat atau tidaknya mengikuti peraturan, menggunakan waktu dengan baik, dan membagikan sesuatu.

e. Perilaku assertive, didominasi oleh kemampuan-kemampuan yang membuat seseorang dapat menampilkan perilaku yang tepat pada kondisi tertentu sesuai dengan yang diharapkan.

\section{Keanggotaan di UKM (X3)}

Kriteria ini diukur dengan menggunakan variabel dummy. Variabel dummy merupakan variabel yang bersifat kategorikal yang diduga mempunyai pengaruh terhadap variabel yang bersifat kontinue. Penelitian ini kriteria mahasiswa yang aktif di UKM diberi nilai 1 dan mahasiswa yang tidak mengikuti UKM diberi nilai 0 . 


\section{ANALISIS DATA}

\section{Statistik Deskriptif}

Statistik deskriptif memberi gambaran mengenai data yang digunakan dalam penelitian. Penggambaran data yang dimaksud meliputi nilai rerata (mean), nilai tertinggi (maximum), nilai terendah (minimum), serta nilai deviasi standar masingmasing variabel yang menggambarkan penyebaran data dalam penelitian.

\section{Analisis Kualitas Data}

\section{Uji Validitas}

Pengujian validitas digunakan untuk menguji ketepatan dalam penggunaan suatu alat ukur penelitian. Penelitian ini menggunakan confirmatory factor analysis (CFA) untuk menguji validitas dengan kriteria jika factor loading $>0,50$, maka indikator dinyatakan valid.

\section{Uji Reliabilitas}

Pengujian reliabilitas dilakukan untuk menunjukkan seberapa jauh kuesioner dapat dipercaya untuk mengukur suatu objek yang akan diukur. Suatu kuesioner dikatakan reliabel jika nilai Cronbach alpha $>0,60$.

\section{Uji Asumsi Klasik}

\section{Uji Normalitas}

Uji normalitas data dilakukan untuk melihat bahwa suatu data terdistribusi secara normal atau tidak. Uji normalitas data dilakukan dengan menggunakan uji statistik non-parametrik Kolmogorov Smirnov (K-S). Dasar pengambilan keputusannya adalah apabila hasil one-sampel Kolmogorov-Smirnov di atas tingkat signifikansi 0,05 menunjukkan pola distribusi normal.

\section{Uji Multikolinieritas}

Uji multikolinieritas bertujuan untuk menguji model regresi ditemukan adanya korelasi antar variabel bebas (independen). Multikolinieritas dapat dilihat dari nilai tolerance dan variance inflation factor (VIF). Jika nilai Tolerance $>0,10$ atau sama dengan nilai VIF $<10$ maka dapat dikatakan tidak ada multikolinieritas antara variabel independen (Ghozali, 2011: 105-106). 


\section{Uji Heteroskedastisitas}

Uji heteroskedastisitas bertujuan untuk menguji ketidaksamaan variance dari residual satu pengamatan ke pengamatan lain dalam model regresi. Model regresi yang baik adalah model regresi yang mempunyai data homoskedastisitas atau tidak terjadi heteroskedastisitas. Pengujian heteroskedastisitas dalam penelitian ini dilakukan dengan uji White. Jika p-value lebih besar dari 0,05 maka dapat disimpulkan model regresi tidak mengandung heteroskedastisitas.

\section{Analisis Regresi Berganda}

\section{Koefisien Determinasi $\left(\mathbf{R}^{2}\right)$}

Koefisien determinasi menyatakan persentase total variasi dari variabel dependen yang dapat dijelaskan oleh variabel independen dalam model. Nilai $\mathrm{R}^{2}$ yang kecil berarti kemampuan variabel-variabel indenpenden dalam menjelaskan variasi variabel dependen amat terbatas. Nilai yang mendekati satu berarti variabelvariabel independen memberikan hampir semua informasi yang dibutuhkan untuk memprediksi variasi-variabel dependen (Ghozali, 2011: 97).

\section{Uji F}

Uji F dilakukan untuk menentukan kelayakan model regresi yang digunakan dalam melakukan analisis hipotesis pada penelitian. Jika nilai signifikansi $<0,05$ maka secara menyeluruh variabel independen berpengaruh terhadap variabel dependen.

\section{HASIL DAN PEMBAHASAN}

\section{Deskripsi Data}

Populasi dalam penelitian ini adalah mahasiswa S1 Program studi Akuntansi UAD yang telah menempuh ujian pendadaran atau menyelesaikan studinya. Berdasarkan kriteria yang telah peneliti tentukan, maka diperoleh jumlah sampel dalam penelitian ini sebanyak 40 mahasiswa. 
Tabel 1

Sampel dan Tingkat Pengembalian

\begin{tabular}{|c|c|c|c|c|}
\hline Responden & $\begin{array}{c}\text { Kuesioner } \\
\text { Disebar }\end{array}$ & $\begin{array}{c}\text { Kuesioner } \\
\text { Kembali }\end{array}$ & $\begin{array}{c}\text { Kuesioner } \\
\text { Dapat } \\
\text { Diolah }\end{array}$ & $\begin{array}{c}\text { Kuesioner } \\
\text { Tidak Dapat } \\
\text { Diolah }\end{array}$ \\
\hline $\begin{array}{c}\text { Mahasiswa S1 Prodi } \\
\text { Akuntansi UAD }\end{array}$ & 46 & 40 & 40 & 6 \\
\hline
\end{tabular}

Sumber: Data primer, diolah (2014)

Pada tabel diuraikan jumlah sampel yang disebar sebanyak 46 buah, kuesioner yang kembali sebanyak 40 buah, kuesioner yang dapat diolah sebanyak 40 buah dan kuesioner yang tidak dapat diolah sebanyak 6 buah.

Tabel 2

Demografi Responden

\begin{tabular}{|l|l|c|l|}
\hline Keterangan & Jumlah & Persentase \\
\hline Jenis Kelamin & Laki- laki & 19 & $47,5 \%$ \\
\hline & Perempuan & 21 & $52,5 \%$ \\
\hline Keterampilan Sosial & Ikut UKM & 17 & $42,5 \%$ \\
\hline & Tidak Ikut UKM & 23 & $57,5 \%$ \\
\hline Lama Studi & $<8$ & 23 & $57,5 \%$ \\
\cline { 1 - 2 } & $>8$ & 17 & $42,5 \%$ \\
\hline
\end{tabular}

Sumber: Data primer, diolah (2014)

\section{Statistik Deskriptif}

Hasil analisis deskriptif menggunakan SPSS adalah sebagai berikut:

Tabel 3

Statistik Deskriptif

\begin{tabular}{|l|l|l|l|l|l|}
\hline Variabel & $\mathbf{N}$ & Minimum & Maximum & Mean & $\begin{array}{l}\text { Std. } \\
\text { Deviaton }\end{array}$ \\
\hline PB_X 1 & 40 & 11 & 15 & 12,92 & 0,997 \\
\hline KS_X 2 & 40 & 10 & 16 & 13,30 & 1,344 \\
\hline UKM_D1 & 40 & 0 & 1 & 0,43 & 0,501 \\
\hline
\end{tabular}

Sumber: Data primer, diolah (2014)

Tabel 3 menunjukkan jumlah responden $(\mathrm{N})$ sebanyak 40 terhadap variabel perilaku belajar (PB) dan keterampilan sosial (KS). perilaku belajar (PB) memiliki nilai minimum sebesar 11 , nilai maksimum sebesar 15 , nilai rata-rata sebesar 12,92 dan deviasi standar sebesar 0,997. Keterampilan sosial (KS) memiliki nilai 
minimum 10, nilai maksimum 16, nilai rata-rata sebesar 13,30 dan deviasi standar sebesar 1,344. Keanggotaan di UKM memiliki nilai minimun sebesar 0 , nilai maksimum sebesar 1, nilai rata- rata sebesar 0,43 dan deviasi standar sebesar 0,501 .

\section{Analisis Kualitas Data}

Uji Validitas

Tabel 4

Hasil Uji Validitas

\begin{tabular}{|l|c|c|c|c|}
\hline \multicolumn{5}{|c|}{ Perilaku Belajar (X1) } \\
\hline No. & Item & Nilai Komponen & Kriteria & Keterangan \\
\hline 1. & $\mathrm{~PB}_{1}$ & 0,790 & 0,50 & Valid \\
& $\mathrm{PB}_{6}$ & 0,689 & 0,50 & Valid \\
& $\mathrm{PB}_{9}$ & 0,765 & 0,50 & Valid \\
& $\mathrm{PB} 12$ & 0,758 & 0,50 & Valid \\
\hline \multicolumn{5}{|c|}{ Keterampilan Sosial (X2) } \\
\hline$\cdot 2$. & $\mathrm{KS}_{3}$ & 0,693 & 0,50 & Valid \\
& $\mathrm{KS}_{7}$ & 0,837 & 0,50 & Valid \\
& $\mathrm{KS}_{8}$ & 0,522 & 0,50 & Valid \\
& $\mathrm{KS} 13^{|c|}$ & 0,773 & 0,50 & Valid \\
\hline
\end{tabular}

Sumber: Data primer, diolah (2014)

Berdasar hasil pengujian validitas dapat di lihat bahwa nilai factor loading dari setiap pernyataan lebih besar dari 0,50. Maka dapat disimpulkan bahwa semua pernyataan dinyatakan valid.

\section{Uji Reliabilitas}

\section{Tabel 5}

Hasil Uji Reliabilitas

\begin{tabular}{|l|l|l|}
\hline Variabel & Nilai Cronbach Alpha & Keterangan \\
\hline Perilaku Belajar & 0,730 & Reliabel \\
\hline Keterampilan Sosial & 0,618 & Reliabel \\
\hline
\end{tabular}

Sumber: Data primer, diolah (2014)

Berdasar hasil pengujian dapat dilihat bahwa variabel perilaku belajar dan keterampilan sosial memiliki nilai cronbach alpha lebih besar dari 0,6 masingmasing sebesar 0,730 dan 0,618. Berdasar hasil tersebut maka instrumen yang digunakan dalam penelitian dinyatakan reliabel. 


\section{Uji Asumsi Klasik}

\section{Uji Normalitas}

Tabel 6

Hasil Uji Normalitas

\begin{tabular}{|l|r|}
\hline & Unstandardized Residual \\
\hline $\mathrm{N}$ & 40 \\
Kolmogorov-Smirnov Z & .835 \\
Asymp. Sig. (2-tailed) & .489 \\
\hline
\end{tabular}

Sumber: Data primer, diolah (2014)

Hasil pengujian normalitas dapat dilihat bahwa nilai signifikansi sebesar 0,489 lebih besar dari taraf signifikansi $0,05(0,489>0,05)$. Berdasar hasil tersebut, dapat diketahui bahwa data terdistribusi normal.

\section{Uji Multikolinieritas}

Tabel 7

Hasil Uji Multikolinieritas

\begin{tabular}{|l|l|c|c|}
\hline \multicolumn{1}{|c|}{ Variabel } & Tolerance & VIF & Keterangan \\
\cline { 3 - 4 } Perilaku Belajar & 0,978 & 1,023 & $\begin{array}{c}\text { Tidak ada } \\
\text { multikolinieritas }\end{array}$ \\
\hline Keterampilan Sosial & 0,936 & 1,069 & $\begin{array}{c}\text { Tidak ada } \\
\text { multikolinieritas }\end{array}$ \\
\hline Keanggotaan di UKM & 0,946 & 1,057 & $\begin{array}{c}\text { Tidak ada } \\
\text { Multikolinieritas }\end{array}$ \\
\hline
\end{tabular}

Sumber: Data primer, diolah (2014)

Hasil pengujian multikolinieritas pada tabel 7, menunjukkan tolerance value semua variabel berada di atas 0,10 dan nilai Variance Inflation Factors (VIF) di bawah 10. Berdasar hasil tersebut, dapat diketahui bahwa tidak terjadi multikolinieritas dalam persamaan regresi berganda.

\section{Uji Heteroskedastisitas}

Tabel 8

Hasil Uji Heteroskedastisitas

\begin{tabular}{|c|c|c|}
\hline P-Value & Alpha & Keterangan \\
\hline 0,8352 & 0,05 & Tidak terjadi heteroskedastisitas \\
\hline
\end{tabular}

Sumber: Data primer, diolah (2014) 
Hasil pengujian heteroskedastisitas pada tabel 8 menunjukkan nilai probabilitas sebesar 0,8352 >0,05. Berdasar hasil tersebut, dapat diketahui bahwa model regresi tidak mengandung heteroskedastisitas.

\section{Analisis Regresi Berganda \\ Koefisien Determinasi $\left(\mathbf{R}^{2}\right)$}

\section{Tabel 9}

Hasil Uji Koefisien Determinasi

\begin{tabular}{|l|l|l|}
\hline Model & $\boldsymbol{R}$ Square & Adjusted $\boldsymbol{R}$ Square \\
\hline 1 & $0, \dot{1} 10$ & 0,036 \\
\hline
\end{tabular}

Sumber: Data primer, diolah (2014)

Tabel 9 menunjukkan nilai adjusted $R$ square adalah 0,036 atau 3,6\%. Hal ini menunjukkan bahwa 3,6\% variabel waktu penyelesaian studi dijelaskan oleh variabel perilaku belajar, keterampilan sosial, dan keanggotaan di UKM. Sedangkan sisanya sebesar 96,4\% dijelaskan oleh faktor-faktor lain di luar model penelitian ini.

\section{Uji F}

\section{Tabel 10}

Hasil Uji F

\begin{tabular}{|c|c|c|c|}
\hline Model & F & Sig. & Alpha \\
\hline Regresi & 1,483 & 0,235 & 0,05 \\
\hline
\end{tabular}

Sumber: Data primer, diolah (2014)

Berdasar hasil pengujian pada tabel 10, menunjukkan nilai $\mathrm{F}$ hitung sebesar 1,483 dan nilai signifikansi sebesar 0,235 . Nilai signifikansi $(0,235)$ lebih besar daripada nilai alpha $(0,05)$ maka model regresi menunjukkan bahwa variabel dependen (waktu penyelesaian studi) secara menyeluruh tidak dipengaruhi oleh variabel independen (perilaku belajar, keterampilan sosial, dan keanggotaan di UKM). 


\section{PEMBAHASAN}

Penelitian ini menggunakan variabel dependen waktu penyelesaian studi dan variabel independen perilaku belajar, keterampilan sosial, dan keanggotaan di UKM. Berdasarkan hasil pengujian yang telah dilakukan dengan menggunakan SPSS, diketahui bahwa hasil pengujian regresi ketiga variabel independen dinyatakan tidak berpengaruh terhadap variabel dependen. Nilai signifikansi $(0,235)$ lebih besar dari alpha $(0,05)$, sehingga model regresi secara menyeluruh tidak dipengaruhi oleh variabel perilaku belajar, keterampilan sosial, dan keanggotaan di UKM. Untuk lebih meyakinkan, peneliti juga melakukan pengujian regresi menggunakan alat uji E-Views. Hasil pengujiaan menunjukkan nilai probabilitas $(0,235456)$ yang lebih besar dari nilai alpha $(0,10)$, maka keseluruhan variabel independen tidak berpengaruh terhadap variabel dependen. Peneliti menduga responden dalam penelitian ini meskipun memiliki keterampilan sosial yang baik, responden tidak mampu membagi waktu antara kegiatan di luar dan di dalam kampus. Meskipun kewajiban studi responden telah terpenuhi mungkin responden belum memenuhi persyaratan kelulusan yang telah ditetapkan oleh Universitas Ahmad Dahlan.

\section{SIMPULAN, KETERBATASAN, DAN SARAN}

Hasil penelitian menunjukkan bahwa perilaku belajar yang baik sebaiknya disertai dengan manajemen waktu yang baik. Begitu pula dengan keterampilan sosial dan keanggotaan dalam kegiatan UKM, mahasiswa sebaiknya memperbanyak pengalaman sehingga diharapkan mampu terus berkembang dan dapat lebih peka terhadap fenomena yang terjadi.

Beberapa keterbatasan penelitian yang dapat ditarik dari penelitian ini adalah sampel dalam penelitian ini sebanyak 40 responden. Peneliti mengalami kesulitan dalam menemukan narasumber karena kriteria responden yang ditentukan adalah mahasiswa yang telah mengikuti ujian pendadaran. Selain itu, pengujian validitas penelitian ini hanya menghasilkan 8 item pernyataan valid dari dua variabel independen yang diukur dengan skala Likert.

Berdasar keterbatasan yang ada, saran untuk penelitian selanjutnya adalah 
diharapkan menambah variabel independen lain yang diduga dapat berpengaruh terhadap waktu penyelesaian studi dan juga melakukan pengujian dibeberapa universitas. Selain itu, diharapkan menambah metoda pengumpulan data selain melalui kuesioner juga melakukan wawancara langsung kepada responden.

\section{DAFTAR PUSTAKA}

Ahmadi, A. 1993. Cara Belajar yang Mandiri dan Sukses. Solo: CV. Aneka.

Ali, M. 1992. Guru dalam Proses Belajar Mengajar. Bandung: CV Sinar Baru.

Aziza, Desy Febrina. 2011. Faktor-faktor yang Mempengaruhi Masa Studi Mahasiswa Jurusan Administrasi Pendidikan FIP Universitas Negeri Malang Tahun Kelulusan Perioda 2008-2010. Skripsi. Malang: Universitas Negeri Malang.

Baskoro, Dios Andri. 2014. Faktor-faktor yang Memotivasi Mahasiswa Menjadi Seorang Entrepreneur. Skripsi. Yogyakarta: Universitas Ahmad Dahlan.

Ghozali, Imam. 2011. Aplikasi Analisis Multivariate dengan Program IBM SPSS 19. Semarang: Badan Penerbit Universitas Diponegoro.

Gujarati, Damodar. 1995. Ekonometrika Dasar. Jakarta: Penerbit Erlangga.

Hair, J.F., Black W.C., Babin B.J., dan Anderson R.E. 2010. Multivariate Data Analysis, $7^{\text {th }}$ ed, New Jersey: Pearson Prentice Hall.

Hamalik, Oemar. 1983. Metoda Belajar dan Kesulitan Kesulitan Belajar. Bandung: Tarsito.

Hanifah. 2001. "Pengaruh Perilaku Belajar terhadap Prestasi Akademik Mahasiswa Akuntansi" Media Riset Akuntansi, Auditing dan Informasi, Vol. 1 No. 3 (Desember) hal. 63-86.

Keterampilan sosial, 2011, [Online] Didapatkan: <http://respository.usu.ac.id/ bitsream/1234579/2350/2/chapter\%20II.pdf [23> Desember 2013]

Rampengan, MJ. 1997. Faktor-faktor Penentu dalam Meningkatkan Prestasi Belajar Mahasiswa PGSD IKIP Manado. Jurnal. Manado: MKP IKIP Manado. 
Sekaran, Uma. 2003. Research Methods for Business: A Skill Building Approach 2nd Edition. New York: John Wiley and Son.

Singarimbun, M \& S. Efendi, 1995, Metoda Penelitian Survey [Online]. Didapatkan http://respository.usu.ac.id [02> Oktober 2013]

Sukma, Aditya. Studi Empiris Pengaruh Kecerdasan Emosional, Perilaku Belajar, dan Stres Kuliah terhadap Keterlambatan Penyelesaian Studi. [Online]. Didapatkan: http://jimfeb.ub.ac.id [02> Oktober 2013]

Sugiyono. 2003. Metoda Penelitian Kuantitatif Kualitatif dan R\&D. Bandung: Alfabeta.

Usman, Uzer. 2000. Menjadi Guru Profesional. Bandung: Rosda karya. 